\title{
Effect of Short Period Incubation During Egg Storage on Hatchability, Embryonic Mortality and Chick Quality Tag EL-Din, T. H. ${ }^{1}$; Z. M. Kalaba ${ }^{2}$; K. H. M .EL-Kholy ${ }^{1}$ and S. A. Abd-EL-Maksoud ${ }^{1}$ ${ }^{1}$ Poult . Production Dept., Fac. of Agric., Demitta. University; Demitta; Egypt. \\ ${ }^{2}$ Poult . Prod. Dept., Fac. of Agric., Mans. University; Mansoura; Egypt.
}

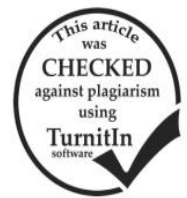

\section{ABSTRACT}

Current experiment conducted on 5850 hatching egg (av. 59.5g) purchased from EL-KASABE for investment Shiver $\mathbb{R}$ Breeder farms ( 34 weeks old). A total of 2250 egg were assigned into 5 treatments of 450 egg representing storage periods of $(0,7,14,21$ and 29 days $)$ and the other 3600 egg were subdivide into 4 groups of 900 egg each according to SPIDES-short period incubation (fresh, $0,2.5$ and 5 hours) at $99.5^{\circ} \mathrm{F}$. After SPIDES, treated egg placed for 2.5 hours in setter room and back into storage room at $12-16^{\circ} \mathrm{C}$ and $75-85 \%$ relative humidity according to the storage time. Egg storage for 7 days had better $(\mathrm{P} \leq 0.05)$ values for fertile egg, hatchability percentages, hatch window, embryonic mortality (early, mid and late), piped and chick quality. However, storage until 29 days showed the lowest significantly $(\mathrm{P} \leq 0.05)$ percent hatchability, hatchability for fertile egg, long incubation time, highest number of total embryonic morality and lowest number of chick quality. SPIDES (2.5 h) recorded higher hatchability traits, but SPIDES 5 hours showed the highest significantly $(\mathrm{P} \leq 0.05)$ number of early embryonic mortality and lowest number of chick quality. Accordingly, when egg stored for more than 7, 14, 21 and 29 days, it should be SPIDES-short period incubation $2.5 \mathrm{~h}$ every five days once, twice or fourth time during storage period to minimize the harmful impact of storage.

Keywords: Egg storage; short period incubation; SPIDES; embryonic mortality

\section{INTRODUCTION}

Storage Egg is a practical process in egg producing farms and hatcheries. Storage period varies between seven days and several, depending on hatching eggs supply, capacity of hatchery, and demand for day old chicks. Usually, eggs are stored for $3^{\text {rd }}$ to $5^{\text {th }}$ days, but in some cases this time increased more than $7^{\text {th }}$ days (Gharib, 2013). Hatching eggs were stored, generally, to minimize transport cost or to collect enough eggs for high capacity incubators. There evidence, however, that egg storage for more than 7 days deteriorated egg albumen and increased embryonic mortality and chicks abnormalities (Van de Ven, 2004) ; incubation time ; reduced hatchability ; Post-hatch performance and chick quality (Petek and Dikmen, 2006 ; Ruiz and Lunam, 2002 and Tona et al., 2003 ). It is also responsible for impairing embryo development and livability (Elibol et al., 2002), with a lag in embryo development (Christensen et al., 2001) due to change metabolism rate (Fasenko et al., 2009), and decline in hatchability (Yassin et al., 2008). Many studies applied to enhance the hatching \% of eggs stored more than $7^{\text {th }}$ days. The most promised one is to warm eggs prior to or during storage (Fasenko, 1997; Anonymous, 2000). Warming of eggs before storage was reported to increase hatchability $\%$ and reduce embryonic mortality (Fasenko et al., 2001a, b).

Therefore, the objective of our study is to illustrate the role of SPIDES- short period of incubation (2.5 and 5 hours) of eggs during egg storage (7, 14, 21 and 29 days) on subsequent hatchability traits.

\section{MATERIALS AND METHODS}

This experiment was done by using 5850 eggs (avg. $59.5 \mathrm{~g}$ ) collected from AL-KASABE for investment Shiver ${ }^{\circledR}$ breeder farms of 34 weeks old laying hens. These were checked for any breakage or abnormality and very small and very large ones removed, then they were kept in the trays and disinfected by Baracleane $5 \AA$ using foam device. The collected eggs were submitted to 5 storage period $(0$, seven, fourteen, twenty one and twenty nine days) treatments $(\mathrm{n}=450 \quad$ eggs/treatment $)$ and 4 short incubation periods (fresh, $0,2.5$ and 5 hours) at $99.5^{\circ} \mathrm{F}$ $(n=900$ eggs $/$ period $)$. After SPIDES treatments, egg placed for two hours in setter's room and back into storage room at $12-16{ }^{\circ} \mathrm{C}$ and $75-85 \% \mathrm{RH}$ according to the storage time. The first treatment in each group as well as a control to group, (T1, T2 andT3) stored 7 days, the second treatment was induced embryonic growth for 2.5 hours once by heating on $99.5{ }^{\circ} \mathrm{F}$ with $60 \% \mathrm{RH}$, egg in the setter, the third treatment was induced embryonic growth for 5 hours once by heating egg in incubation machine. (T4, T5 and T6) stored 14 days, T5 promote the activity of the embryonic cells twice by heating eggs for a period of 2.5 hours, T6 promote the activity of the embryonic cells twice by heating eggs for a period of 5 hours. (T7, T8 and T9) stored 21 days, T8 and T9 are induced embryonic growth fourth time 2.5 and 5 hours, respectively. (T10, T11 and T12) stored 29 days, T11 and $\mathrm{T} 12$ are induced fifth time 2.5 and 5 hours, respectively. Temperature of the incubator was $99.5^{\circ} \mathrm{F}$ with $60 \% \mathrm{RH}$ for first 18 days, and then eggs were transferred to hatcher. Tables 1, 2, 3 and 4 summarizes the main operating processes in the hatchery.

Table 1. Hatchery Program Temperature $\left({ }^{\circ}\right.$ F).

\begin{tabular}{|c|c|c|c|c|}
\hline Phase & Temp. $\left({ }^{\circ} \mathbf{F}\right)$ & \multirow{2}{*}{\multicolumn{3}{|c|}{$\begin{array}{c}\text { Process Time } \\
\text { Day: hour }\end{array}$}} \\
\hline & & & & \\
\hline One & 98.8 & 18 & & 1 \\
\hline Two & 98.5 & 19 & : & 4 \\
\hline Three & 98.3 & 20 & : & 4 \\
\hline Four & 98.0 & 20 & : & 15 \\
\hline Five & 97.5 & 20 & : & 18 \\
\hline Six & 97.0 & 21 & : & 6 \\
\hline
\end{tabular}

Temperature programmed separately.

Table 2. Hatchery Program Humidity $\left({ }^{\circ} \mathrm{F}\right)$.

\begin{tabular}{lcc}
\hline Phase & Wet bulb & Time \\
\hline & & Day $:$ hour \\
One & 86 & $18: 2$ \\
Two & 93 & $19: 7$ \\
Three & 89 & $20: 19$ \\
Four & 87 & $21: 7$ \\
\hline
\end{tabular}


Table 3. Hatchery program Ventilation (\%).

\begin{tabular}{lrrc}
\hline Phase & \multicolumn{2}{c}{$\%$} & Time \\
& Min & Max & Day : hour \\
\hline One & 20 & 55 & $18: 01$ \\
Two & 20 & 30 & $19: 12$ \\
Three & 40 & 75 & $20: 03$ \\
Four & 55 & 85 & $20: 13$ \\
Five & 70 & 95 & $20: 16$ \\
Six & 85 & 95 & $21: 7$ \\
\hline
\end{tabular}

Table 4. Hatch Cooling program.

\begin{tabular}{lcc}
\hline Phase & System & Time \\
\hline & & Day : hour \\
one & $\mathrm{H}_{2} \mathrm{O}$ & $18: 1$ \\
two & $\mathrm{H}_{2} \mathrm{O}+\mathrm{O}_{2}$ delayed & $19: 00$ \\
three & $\mathrm{H}_{2} \mathrm{O}+\mathrm{O}_{2}$ & $20: 18$ \\
\hline
\end{tabular}

Eggs in experiment weighted after collection and at the end of storage period. Fertility $\%$ calculated at the end of incubation period by using equation.

$$
\text { Fertility }(\%)=\frac{\text { Number of Fentle eggs }}{\text { Number of total eggs }} \times 100
$$

Unhatched eggs were taken and broken out to determine early and late embryonic mortality and pips (live and dead).

Data were analyzed by General Linear Model (GLM) procedures of SAS (2004) .The differences between means were tested by the multiple range test (Duncan ,1955).

\section{RESULTS AND DISCUSSION}

Effect of short period incubation one time (2.5 and 5 h) and prolonged egg storage ( 7 days) on hatchability characteristics:

Data of short period incubation one time (2.5 and $5 \mathrm{~h}$ ) and prolonged egg storage (7 days) on hatchability characteristics were summarized in Table 5. Short period incubation one time $2.5 \mathrm{~h}$ showed the best value significantly on hatchability $\%$, hatchability of fertile egg\%, hatch window, un-fertile egg, early embryonic mortality (0-7 day) and chick quality (chicks grade A) (91.33\%, 96.94\%, 504.33, 3.00, 2.33 and 137.00 respectively) when compared with the other short period incubation $5 \mathrm{~h}$ or egg which incubation immediately (treatment fresh) or control group. On the other hand, the lowest percent for hatchability when stored egg 29 day $(0 \%)$ and longest incubation period (hatch window "520.66 h") compared with egg stored 21 days which achieved (33.11\% hatchability percent and 515.33 hatch window). Embryonic mortality achieved the highest value (142.33) when stored egg 29 days compared with the other prolonged egg storage $0,7,14$ and 21 days (6.66, 6.33, 23.66 and 84.66 respectively). Few of embryos long storage periods may be failed to start their development soon or they can grow at a slower rate during the first days of incubation. This result is in close agreement with the previous reports on broilers, turkey and Japanese quail chicks (Uddin et al., 1994; Anonymous, 2000; Fasenko et al., 2001a,b).

Table 5. Influence of storage period ( 7 days) and short -term incubation of eggs for 2.5 and $5 \mathrm{~h}$ at $99.5^{\circ} \mathrm{F}$ on hatchability traits.

\begin{tabular}{|c|c|c|c|c|c|c|c|c|c|c|c|c|c|}
\hline \multirow{2}{*}{ Treatment } & \multicolumn{4}{|c|}{ Incubation characteristics } & \multicolumn{3}{|c|}{ Embryonic mortality } & \multicolumn{2}{|c|}{ Piped } & \multirow[b]{2}{*}{$\begin{array}{l}\text { Cont } \\
\text { man }\end{array}$} & \multicolumn{3}{|c|}{ Chick quality } \\
\hline & $\begin{array}{c}\text { Hatch } \\
\%\end{array}$ & $\begin{array}{c}\text { Hatch } \\
\text { FE\% }\end{array}$ & $\begin{array}{l}\text { Hatc } \\
\text { Win }\end{array}$ & Unfert & $0-7$ & 8-14 & 15-21 & $\begin{array}{l}\text { Live } \\
\text { pip }\end{array}$ & $\begin{array}{c}\text { Dead } \\
\text { pip }\end{array}$ & & $\mathbf{A}$ & B & $\mathbf{C}$ \\
\hline Store & & & & & & & & & & & & & \\
\hline 0 & $90.88^{\mathrm{a}}$ & $96.69^{\mathrm{ab}}$ & $504.3^{\mathrm{e}}$ & $3.0^{\mathrm{d}}$ & $6.66^{\mathrm{d}}$ & $1.0^{\mathrm{b}}$ & $2.0^{\mathrm{c}}$ & $1.0^{\mathrm{b}}$ & $0.0^{\mathrm{b}}$ & $0.0^{\mathrm{c}}$ & $136.3^{\mathrm{a}}$ & 0.0 & 0.0 \\
\hline 7 & $84.0^{\mathrm{b}}$ & $91.64^{\mathrm{b}}$ & $507.3^{\mathrm{d}}$ & $8.66^{\mathrm{a}}$ & $6.33^{\mathrm{d}}$ & $2.0^{\mathrm{a}}$ & $3.0^{\mathrm{b}}$ & $0.7^{\mathrm{b}}$ & $0.7^{\mathrm{a}}$ & $0.7^{\mathrm{bc}}$ & $126.0^{\mathrm{b}}$ & 1.34 & 0.66 \\
\hline 14 & $78.88^{\mathrm{c}}$ & $97.79^{\mathrm{a}}$ & $512.3^{\mathrm{c}}$ & $6.0^{\mathrm{c}}$ & $23.66^{\mathrm{c}}$ & $0.0^{\mathrm{c}}$ & $1.0^{\mathrm{d}}$ & $0.0^{\mathrm{c}}$ & $0.0^{\mathrm{b}}$ & $1.0^{\mathrm{b}}$ & $118.3^{\mathrm{c}}$ & 0.0 & 0.0 \\
\hline 21 & $33.11^{\mathrm{d}}$ & $80.42^{\mathrm{c}}$ & $515.3^{\mathrm{b}}$ & $2.0^{\mathrm{e}}$ & $84.66^{\mathrm{b}}$ & $0.33^{\mathrm{c}}$ & $4.0^{\mathrm{a}}$ & $6.0^{\mathrm{a}}$ & $0.0^{\mathrm{b}}$ & $2.34^{\mathrm{a}}$ & $49.6^{\mathrm{d}}$ & 0.0 & 1.0 \\
\hline 29 & $0.0^{\mathrm{e}}$ & $0.00^{\mathrm{d}}$ & $520.6^{\mathrm{a}}$ & $7.33^{\mathrm{b}}$ & $142.33^{\mathrm{a}}$ & $0.0^{\mathrm{c}}$ & $0.33^{\mathrm{d}}$ & $0.0^{\mathrm{c}}$ & $0.0^{\mathrm{b}}$ & $0.0^{\mathrm{c}}$ & $0.00^{\mathrm{e}}$ & 0.0 & 0.0 \\
\hline SE & 0.95 & 1.75 & 0.84 & 0.21 & 1.20 & 0.14 & 0.29 & 0.14 & 0.14 & 0.21 & 1.43 & 0.39 & 0.29 \\
\hline Sig & $* *$ & $* *$ & $* *$ & $* *$ & $* *$ & $* *$ & $* *$ & $* *$ & $*$ & $* *$ & $* *$ & N.S & N. S \\
\hline SPIDES & $90.88^{\mathrm{a}}$ & & $504.3^{\mathrm{b}}$ & & & & & & & & & & \\
\hline (Control) & $84.0^{\mathrm{c}}$ & $91.64^{b}$ & $507.3^{\mathrm{a}}$ & $8.66^{\mathrm{a}}$ & $6.33^{\mathrm{a}}$ & 2.0 & 3.0 & 0.66 & 0.66 & 0.66 & $126.0^{\mathrm{c}}$ & 1.33 & 0.66 \\
\hline$(2.5 \mathrm{~h})$ & $91.33^{\mathrm{a}}$ & $96.94^{\mathrm{a}}$ & $504.3^{\mathrm{b}}$ & $3.0^{\mathrm{c}}$ & $2.33^{\mathrm{b}}$ & 1.33 & 2.0 & 1.33 & 1.0 & 1.33 & $137.0^{\mathrm{a}}$ & 0.66 & 0.0 \\
\hline$(5 \mathrm{~h})$ & $88.66^{\mathrm{b}}$ & $94.83^{\mathrm{a}}$ & $503.3^{\mathrm{b}}$ & $4.0^{\mathrm{b}}$ & $6.0^{\mathrm{a}}$ & 0.66 & 2.33 & 0.66 & 1.0 & 0.66 & $133.0^{\mathrm{b}}$ & 1.0 & 0.66 \\
\hline $\mathrm{SE}$ & 0.44 & 0.68 & 0.33 & 0.16 & 0.50 & 0.37 & 0.44 & 0.28 & 0.33 & 0.40 & 0.66 & 0.62 & 0.23 \\
\hline Sig & $* *$ & $* *$ & $* *$ & $* *$ & $* *$ & N. S & N. S & N. S & N.S & N. S & $* *$ & N. S & N. S \\
\hline
\end{tabular}

${ }^{a-e}$ : Means with different superscripts within the same row are significantly different at $P<0.05$.

Results are Corresponds with those by Petek and Dikmen (2004) they reported better fertility of egg stored for $5^{\text {th }}$ days than those stored for $15^{\text {th }}$ days. Petek et al. (2003), Petek and Dikmen (2004) observed that, long period storage decreased apparent fertility. But, Elibol et al. (2002) and Gharib (2013) didn't find any significant effects on the apparent fertility when they stored eggs for four, seven, ten and fourteen days at $18^{\circ} \mathrm{C}$ and $75 \%$ RH. Pre-heating treatment didn't show any influence significant on number of fertile eggs and fertility\%. Similarly, Reijrink et al. (2010) failed to detect any influence significant on the same parameters among pre-storage heat exposure for 0,6 , and 9 hours at $37.5^{\circ} \mathrm{C}$ and $56 \% \mathrm{RH}$. of broiler. Although, Petek and Dikmen (2006) demonstrated that warming broiler eggs for 4 and $8 \mathrm{~h}$ at $38.0^{\circ} \mathrm{C}$ significantly decreased fertility compared to control eggs. 
Effect of short period incubation twice time (2.5 and 5 h) and prolonged egg storage (14 days) on hatchability characteristics:

Data of both hatchability percentages, hatch window, embryonic mortality, number and quality of chicks are illustrated in Table 6. It appears that the best significant values for hatchability, hatch window, lowest value for unfertile egg, lowest early embryonic mortality and highly number of chick grad A at hatch $(90.88 \%, 504.33,3.00$, 6.66 and 136.33 respectively) when compared with other treatment non warmed $(78.88 \%, 512.33,6.00,23.66$ and 118.33 respectively) or treatments were exposed to short period incubation 2.5 or $5 \mathrm{~h}(86.22 \%, 87.55 \%, 505.66$, 505.66, 6.00, 6.00, 7.66, 10.33, 129.33 and 131.33). But, this doesn't happen on commercial scale; eggs are stored for at least 4 days. The eggs are heated twice during storage period 7, 14 or 21 day shows the best results for fertility of fertilized eggs (96.94\%, 95.41\% and 93.05\% respectively) compared to egg storage 29 day $(92.07 \%)$. Similar results was obtained by Yassin et al.( 2008) who reported that preheating of eggs influenced the metabolic activity of the chick embryo, which in turn affects its development . Moreover, several researches, dealing with this subject, mentioned other factors including egg aging (Tarongoy et al., 1990), storage period (Brah and Sandhu, 1989), hen's age (Rogue and Soares, 1994), management (Weis, 1991), sex ratio and mating behavior (Gebhardt-Henrich and Mark, 1991) and incubation conditions .

Table 6. Influence of storage period (14 days) and short-term incubation of eggs for 2.5 and $5 \mathrm{~h}$ at $99.5^{\circ} \mathrm{F}$ on hatchability traits.

\begin{tabular}{|c|c|c|c|c|c|c|c|c|c|c|c|c|c|}
\hline \multirow[b]{2}{*}{ Treatment } & \multicolumn{4}{|c|}{ Incubation characteristics } & \multicolumn{3}{|c|}{ Embryonic mortality } & \multicolumn{2}{|c|}{ Piped } & \multirow[b]{2}{*}{$\begin{array}{l}\text { Cont } \\
\text { man }\end{array}$} & \multicolumn{3}{|c|}{ Chick quality } \\
\hline & $\begin{array}{c}\text { Hatch } \\
\%\end{array}$ & $\begin{array}{l}\text { Hatch } \\
\text { FE\% }\end{array}$ & $\begin{array}{l}\text { Hatc } \\
\text { Win }\end{array}$ & Unfert & $0-7$ & 8-14 & $15-21$ & $\begin{array}{l}\text { Live } \\
\text { pip }\end{array}$ & $\begin{array}{c}\text { Dead } \\
\text { pip }\end{array}$ & & $\mathbf{A}$ & B & $\mathbf{C}$ \\
\hline Storage & & & & & & & & & & & & & \\
\hline 0 & $90.88^{\mathrm{a}}$ & $96.69^{\mathrm{a}}$ & $504.3^{\mathrm{b}}$ & $3.00^{\mathrm{d}}$ & $6.66^{\mathrm{c}}$ & $1.0^{\mathrm{b}}$ & $2.0^{\mathrm{c}}$ & $1.0^{\mathrm{a}}$ & $0.0^{\mathrm{b}}$ & $0.0^{\mathrm{b}}$ & $136.3^{\mathrm{a}}$ & 0.0 & $0.0^{\mathrm{b}}$ \\
\hline 7 & $91.33^{\mathrm{a}}$ & $96.94^{\mathrm{a}}$ & $504.3^{\mathrm{b}}$ & $3.0^{\mathrm{d}}$ & $2.33^{\mathrm{d}}$ & $1.33^{\mathrm{b}}$ & $2.0^{\mathrm{c}}$ & $1.33^{\mathrm{a}}$ & $1.0^{\mathrm{a}}$ & $1.33 \mathrm{a}$ & $137.0^{\mathrm{a}}$ & 0.66 & $0.0^{\mathrm{b}}$ \\
\hline 14 & $86.22^{\mathrm{b}}$ & $\underset{\mathrm{b}}{95.41^{\mathrm{a}}}$ & $505.6^{\mathrm{b}}$ & $6.0^{\mathrm{b}}$ & $7.66^{\mathrm{c}}$ & $1.0^{\mathrm{b}}$ & $2.33^{\mathrm{c}}$ & $0.66^{\mathrm{a}}$ & $0.66^{\mathrm{a}}$ & $0.0^{\mathrm{b}}$ & $129.3^{\mathrm{b}}$ & 1.66 & $0.66^{\mathrm{a}}$ \\
\hline 21 & $83.33^{\mathrm{c}}$ & $\underset{\mathrm{c}}{93.05^{\mathrm{b}}}$ & $507.3^{\mathrm{a}}$ & $3.66^{\mathrm{c}}$ & $12.0^{\mathrm{b}}$ & $3.0^{\mathrm{a}}$ & $5.66^{\mathrm{b}}$ & $0.0^{\mathrm{b}}$ & $0.0^{\mathrm{b}}$ & $0.66^{\mathrm{b}}$ & $125.0^{\mathrm{c}}$ & 0.0 & $0.0^{\mathrm{b}}$ \\
\hline 29 & $61.55^{\mathrm{d}}$ & $92.07^{\mathrm{c}}$ & $508.3^{\mathrm{a}}$ & $7.0^{\mathrm{a}}$ & $39.66^{\mathrm{a}}$ & $0.66^{\mathrm{b}}$ & $7.66^{\mathrm{a}}$ & $1.0^{\mathrm{a}}$ & $1.0^{\mathrm{a}}$ & $0.0^{\mathrm{b}}$ & $92.33^{d}$ & 0.66 & $0.0^{\mathrm{b}}$ \\
\hline SE & 0.57 & 0.76 & 0.42 & 0.14 & 0.39 & 0.21 & 0.51 & 0.21 & 0.14 & 0.21 & 0.85 & 0.57 & 0.14 \\
\hline Sig & $* *$ & $* *$ & $* *$ & $* *$ & $* *$ & $*$ & $* *$ & $*$ & $* *$ & $* *$ & $* *$ & N.S & $*$ \\
\hline $\begin{array}{l}\text { SPIDES } \\
\text { (fresh) }\end{array}$ & $90.88^{\mathrm{a}}$ & 96.69 & $504.3^{\mathrm{b}}$ & $3.0^{\mathrm{b}}$ & $6.66^{\mathrm{c}}$ & 1.0 & 2.0 & $1.0^{\mathrm{a}}$ & 0.0 & $0.0^{\mathrm{b}}$ & $136.3^{\mathrm{a}}$ & 0.0 & 0.0 \\
\hline (Control) & $78.88^{\mathrm{c}}$ & 97.79 & $512.3^{\mathrm{a}}$ & $6.0^{\mathrm{a}}$ & $23.66^{\mathrm{a}}$ & 0.0 & 1.0 & 0.0 & 0.0 & $1.0^{\mathrm{a}}$ & $118.3^{\mathrm{c}}$ & 0.0 & 0.0 \\
\hline$(2.5 \mathrm{~h})$ & $86.22^{\mathrm{b}}$ & 95.41 & $505.6^{\mathrm{b}}$ & $6.0^{\mathrm{a}}$ & $7.66^{\mathrm{c}}$ & 1.0 & 2.33 & $0.66^{\mathrm{a}}$ & 0.66 & $0.0^{\mathrm{b}}$ & $129.3^{b}$ & 1.66 & 0.66 \\
\hline$(5 \mathrm{~h})$ & $87.55^{\mathrm{b}}$ & 97.52 & $505.6^{\mathrm{b}}$ & $6.33^{\mathrm{a}}$ & $10.33^{\mathrm{b}}$ & 0.0 & 2.0 & 0.0 & 0.0 & $0.0^{\mathrm{b}}$ & $131.3^{\mathrm{b}}$ & 0.0 & 0.0 \\
\hline $\mathrm{SE}$ & 0.52 & 0.62 & 0.60 & 0.16 & 0.60 & 0.22 & 0.44 & 0.16 & 0.16 & 0.00 & 0.78 & 0.44 & 0.16 \\
\hline Sig & $* *$ & N. S & $* *$ & $* *$ & $* *$ & N.S & N. S & $* *$ & N. S & $* *$ & $* *$ & N.S & N. S \\
\hline
\end{tabular}

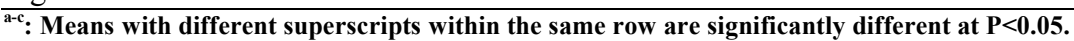

furthermore, Petek et al. (2005) who used quail's eggs, indicated that hatchability of fertile and total eggs was not affected by length of storage period of $1,3,5$, or $7 \mathrm{~d}$. Egg storage 29 day had the lowest hatchability percentages (61.55\% and 92.077\%) compared with nonwarmed, warmed for 2.5 and 5 hours $(86.22$ and $87.55 \%$, 95.41 and $97.52 \%$ respectively), but control treatment ( 0 hours) showed the highest significantly values for early embryonic mortality (23.66) when compared with other warming treatments 2.5 and 5 hours (7.66 and $10.33 \mathrm{~g}$, respectively).

Storage eggs longer than $7^{\text {th }}$ days increased embryonic mortality and decreased hatchability \% and chick grade (Fasenko, 2007; Hamidu et al., 2011). This negative effect may be caused by changes in the embryo or in the egg characteristics, or by both (Reijrink et al., 2010). Moreover, Marandure et al. (2012) exposed broiler breeder eggs to $4,8,12 \mathrm{~h}$ warming, they found that hatchability decreased with time. This was not observed by Gucbilmez et al. (2013) who reported no benefit effect of heating broiler breeder's eggs for $1 \mathrm{~d}$ of a 6 - $\mathrm{d}$ storage period on hatchability percentage, although the storage periods by pre-heating interaction effect was significant on both hatchability and chick weight at hatch.
Effect of short period incubation fourth time (2.5 and 5 h) and prolonged egg storage ( 21 days) on hatchability characteristics, embryonic mortality, pips and abnormal chicks:

The influence of $21 \mathrm{~d}$ storage and warming on hatchability characteristics is presented in Table 7 . It is clear that $29 \mathrm{~d}$ storage caused lower hatchability $(31.55 \%)$ when compared with other storage periods $(88.66,87.55$ and 69.11$)$ of 7,14 and 21 days of storage, respectively . Also the highest embryonic morality (77.33, 4 and 10 for early, mid and late embryonic mortality) was observed for this treatment compared to other treatments $(6.00,0.66$ and 2.33 for 7 days of storage, $10.00,0.00$ and 2.00 for 14 days of storage and 22.00 , 10.00 and 10.33 for 21 days of storage respectively). It was also found, the storage period 29 days show highly significant differences on pips (live or dead) and lowest significant differences on chicks grade.

Warming egg at 2.5 and 5 hours showed the highest significant $(\mathrm{P} \leq 0.05)$ hatchability $\%$, hatchability for fertile egg, hatch window and lowest significant for early embryonic mortality (0-7 day), mid embryonic mortality (8-14 day) and showed highest significant for chick quality as showed in table 7 when compared with control. 
Tag EL - Din, T. H. et al.

Table 7. Influence of storage period ( 21 days) and short -term incubation of eggs for 2.5 and $5 \mathrm{~h}$ at $99.5^{\circ} \mathrm{F}$ on hatchability traits.

\begin{tabular}{|c|c|c|c|c|c|c|c|c|c|c|c|c|c|}
\hline \multirow[b]{2}{*}{ Treatment } & \multicolumn{4}{|c|}{ Incubation characteristics } & \multicolumn{3}{|c|}{ Embryonic mortality } & \multicolumn{2}{|c|}{ Piped } & \multirow[b]{2}{*}{$\begin{array}{l}\text { Cont } \\
\text { man }\end{array}$} & \multicolumn{3}{|c|}{ Chick quality } \\
\hline & $\begin{array}{c}\text { Hatch } \\
\%\end{array}$ & $\begin{array}{c}\text { Hatch } \\
\text { FE }\end{array}$ & $\begin{array}{l}\text { Hatc } \\
\text { Win }\end{array}$ & Unfert & $0-7$ & 8-14 & $15-21$ & $\begin{array}{l}\text { Live } \\
\text { pip }\end{array}$ & $\begin{array}{c}\text { Dead } \\
\text { pip }\end{array}$ & & $\mathbf{A}$ & B & $\mathbf{C}$ \\
\hline \multicolumn{14}{|l|}{$\overline{\text { Storage }}$} \\
\hline 0 & $90.88^{\mathrm{a}}$ & $96.69^{\mathrm{ab}}$ & $504.33^{\mathrm{c}}$ & $3.00^{\mathrm{bc}}$ & $6.66^{\mathrm{d}}$ & $1.00^{\mathrm{c}}$ & $2.00^{\mathrm{b}}$ & $1.00^{\mathrm{b}}$ & $0.0^{\mathrm{b}}$ & $0.00^{\mathrm{b}}$ & $136.3^{\mathrm{a}}$ & 0.00 & 0.00 \\
\hline 7 & $88.66^{\mathrm{b}}$ & $94.83^{\mathrm{b}}$ & $503.33^{c}$ & $4.00^{\mathrm{bc}}$ & $6.00^{\mathrm{d}}$ & $0.7^{\mathrm{cd}}$ & $2.33^{\mathrm{b}}$ & $0.66^{\mathrm{b}}$ & $1.0^{\mathrm{b}}$ & $0.66^{\mathrm{b}}$ & $133.0^{\mathrm{b}}$ & 1.00 & 0.66 \\
\hline 14 & $87.55^{\mathrm{b}}$ & $97.52^{\mathrm{a}}$ & $505.66^{\mathrm{b}}$ & $6.33^{\mathrm{a}}$ & $10.33^{\mathrm{c}}$ & $0.0^{\mathrm{d}}$ & $2.00^{\mathrm{b}}$ & $0.00^{\mathrm{c}}$ & $0.0^{\mathrm{b}}$ & $0.00^{\mathrm{b}}$ & $131.3^{\mathrm{b}}$ & 0.00 & 0.00 \\
\hline 21 & $69.11^{\mathrm{c}}$ & $82.80^{\mathrm{c}}$ & $506.66^{\mathrm{b}}$ & $2.00^{\mathrm{c}}$ & $22.00^{\mathrm{b}}$ & $10.0^{\mathrm{a}}$ & $10.4^{\mathrm{c}}$ & $1.00^{\mathrm{b}}$ & $0.33^{\mathrm{b}}$ & $0.00^{\mathrm{b}}$ & $103.7^{\mathrm{c}}$ & 0.33 & 0.33 \\
\hline 29 & $31.55^{\mathrm{d}}$ & $70.37^{\mathrm{d}}$ & $508.33^{\mathrm{a}}$ & $4.33^{\mathrm{b}}$ & $77.33^{\mathrm{a}}$ & $4.00^{\mathrm{b}}$ & $10.0^{\mathrm{c}}$ & $2.00^{\mathrm{a}}$ & $2.00^{\mathrm{a}}$ & $2.00^{\mathrm{a}}$ & $47.33^{\mathrm{d}}$ & 1.00 & 0.00 \\
\hline $\mathrm{SE}$ & 0.60 & 0.69 & 0.42 & 0.61 & 0.44 & 0.29 & 0.33 & 0.14 & 0.29 & 0.39 & 0.90 & 0.39 & 0.21 \\
\hline Sig & $* *$ & $* *$ & $* *$ & $* *$ & $* *$ & $* *$ & $* *$ & $* *$ & $* *$ & $*$ & $* *$ & N.S & N.S \\
\hline \multicolumn{14}{|l|}{ SPIDES } \\
\hline $\begin{array}{l}0 \\
\text { (fresh) }\end{array}$ & $90.88^{\mathrm{a}}$ & $96.69^{\mathrm{a}}$ & $504.33^{c}$ & $3.00^{\mathrm{b}}$ & $6.66^{\mathrm{d}}$ & $1.00^{\mathrm{c}}$ & $2.00^{\mathrm{d}}$ & $1.00^{\mathrm{b}}$ & 0.00 & $0.00^{\mathrm{b}}$ & $136.3^{\mathrm{a}}$ & 0.00 & 0.00 \\
\hline (Control) & $33.11^{\mathrm{d}}$ & $80.42^{b}$ & $515.33^{\mathrm{a}}$ & $2.00^{\mathrm{c}}$ & $84.66^{\mathrm{a}}$ & $0.33^{\mathrm{d}}$ & $4.00^{c}$ & $6.00^{\mathrm{a}}$ & 0.00 & $2.33^{\mathrm{a}}$ & $49.66^{\mathrm{d}}$ & 0.00 & 1.00 \\
\hline$(2.5 \mathrm{~h})$ & $83.33^{\mathrm{b}}$ & $93.05^{\mathrm{a}}$ & $507.33^{b}$ & $3.66^{\mathrm{a}}$ & $12.00^{\mathrm{c}}$ & $3.00^{\mathrm{b}}$ & $5.66^{\mathrm{b}}$ & $0.00^{\mathrm{c}}$ & 0.00 & $0.66^{\mathrm{b}}$ & $125.0^{\mathrm{c}}$ & 0.00 & 0.00 \\
\hline$(5 \mathrm{~h})$ & $69.11^{\mathrm{c}}$ & $82.80^{\mathrm{b}}$ & $506.7^{\mathrm{bc}}$ & $2.00^{c}$ & $22.00^{\mathrm{b}}$ & $10.0^{\mathrm{a}}$ & $10.3^{\mathrm{a}}$ & $1.00^{\mathrm{b}}$ & 0.33 & $0.00^{\mathrm{b}}$ & $103.7^{\mathrm{b}}$ & 0.33 & 0.33 \\
\hline $\mathrm{SE}$ & 1.07 & 1.90 & 0.78 & 0.16 & 1.24 & 0.16 & 0.37 & 0.00 & 0.16 & 0.23 & 1.60 & 0.16 & 0.33 \\
\hline Sig & $* *$ & $* *$ & $* *$ & $* *$ & $* *$ & $* *$ & $* *$ & $* *$ & N.S & $* *$ & $* *$ & N.S & N.S \\
\hline
\end{tabular}

a-c: Means with different superscripts within the same row are significantly different at $\mathrm{P}<0.05$.

Similar findings was reported by Reijrink et al. (2010) and Gharib (2013) who found significantly higher late embryonic mortality rate for egg stored for 10 and $14 \mathrm{~d}$ compared to 4 and $7 \mathrm{~d}$ storage. Hamidu et al. $(2010,2011)$ explained the deleterious effect of prolonged storage on broiler and layer blastodermal cell viability, cell death and embryo survival. The extent of embryonic metabolic imbalance created by prolonged egg storage and what implications embryonic metabolism might have on suppressing embryonic cell viability, embryo growth and chick grade was not clear . In this concern, Petek and Dikmen (2006) indicated that exposure of eggs for 4 and $8 \mathrm{~h}$ to $38.0^{\circ} \mathrm{C}$ significantly increased embryonic mortality compared to non-heated eggs.

In general, the present results clearly indicated that embryonic mortality was greater in egg stored for 29 and 21 days and this is reflected on hatchability.

\section{CONCLUSION}

Our study provides evidence that long term storage of eggs (21 and 29 days) adversely affects all hatching traits. It is recommended that when storage of eggs more than seven days is urgently important, one should warm eggs for $2.5 \mathrm{~h}$ every five days to minimize the harmful impact of storage.

\section{REFERENCES}

Anonymous (2000). Preheating of ostrich eggs. Int. Hatch. Pract., 14 (Abstract), 32.

Brah, G.S. and J.S. Sandhu, (1989). Pre-incubation storage of guinea fowl eggs in cooling cabinet vs. room: Effect on hatchability components. Agric. (Trinidad and Tobago), 66: 265-268.

Christensen, V. L., M. J. Wineland, G. M. Fasenko, and W. E. Donaldson. (2001). Egg storage effects on plasma glucose and supply and demand tissue glycogen concentrations of broiler embryos. Poult. Sci. 80:1729-1735.
Duncan, D.B. (1955). Multiple range and multiple F test. Biometrics, 11: 1-42.

Elibol, O.; S. D. Peak and J. Brake (2002). Effect of flock age, length of egg storage, and frequency of turning during storage on hatchability of broiler hatching eggs. Poultry Science, 81:945-950.

Fasenko G. (1997). How are embryo and poult viability, hatchability, and growth affected by storing turkey eggs for long periods. Alberta Poultry Research Centre News, 6, 1.

Fasenko GM (2007). Egg storage and embryo. Poult. Sci., 86: 1020-1024.

Fasenko G.M., V.L. Christensen, M.J. Wineland and J.N. Petitte (2001a). Examining the effects of pre-storage incubation of turkey breeder eggs on embryonic development and hatchability of stored for four or fourteen days. Poult. Sci., 80, 132-138.

Fasenko G.M., F.E. Robinson, A.I. Whelan, K.M. Kremeniuk and J.A. Walker (2001b). Pre-storage incubation of long-term stored broiler eggs; 1. Effects on hatchability. Poult. Sci., 80, 1406-1411.

Fasenko, G. M., F. E. Robinson, and V. L. Christensen (2009). Effects of long term storage on the egg, embryo and chick. Avian Biological Research, 2:73-79.

Gebhardt-Henrich, S.G. and H.L. Mark, (1991). The effect of switching males among caged females on egg production and hatchability in Japanese quail. Poult. Sci., 70: 1845-1847.

Gharib H.B. (2013). Effect of pre-storage heating of broiler breeder eggs, stored for long periods, on hatchability and chick quality. Egyptian J. Anim. Prod. 50(3):174 -184

Gucbilmez , M.; S. Ozlu ; R. Shiranjang; O. Elibol and J. Brake (2013). Effects of preincubation heating of broiler hatching eggs during storage, flock age, and length of storage period on hatchability. Poult. Sci.,92:3310-3313. 
Hamidu JA, Rieger A, Fasenko GM, Barreda DR (2010). Dissociation of chicken blastoderm for examination of apoptosis and necrosis by flow cytometry. Poult. Sci., 89: 901-909.

Hamidu JA, Uddin Z, Fasenko GM, Guan LL, Barreda DR (2011). Broiler egg storage induces cell death and influences embryo quality. Poult. Sci., 90: 1749-1757.

Marandure T., Matondi G. H. Nyamushamba G. B. and Ganyani B. (2012). Effect of duration of preheating broiler breeder eggs on hatchability, egg weight and chick uniformity post hatch. Research Journal of Agricultural and Environmental Management Vol. 1(1) : $1-5$.

Petek M., Dikmen S. (2004). The effects of prestorage incubation of quail breeder eggs on hatchability and subsequent growth performance of progeny. Anim. Res., 53, 527-534.

Petek, M. and S. Dikmen (2006). The effects of prestorage incubation and length of storage of broiler breeder eggs on hatchability and subsequent growth performance of progeny. Czech J. Anim. Sci., 51(2): 73-77.

Petek M., Baspinar H., Ogan M. (2003). Effects of egg weight and length of storage period on hatchability and subsequent growth performance of quail. S. Afric. J.Anim. Sci., 4, 242-247.

Petek, M.; H. Baspinar, M. Ogan, F. Balci (2005). Effects of egg weight and length of storage period on hatchability and subsequent laying performance of Quail. Turk J. Vet. Anim. Sci, 29: 537-542.

Reijrink, I. M.; D. Berghmans; R. Meijerhof ; B. Kemp and H. Van den Brand (2010). Influence of egg storage time and preincubation warming profile on embryonic development, hatchability, and chick quality. Poult. Sci.,89:1225-1238

Renema, R. A., J. J. R. Feddes, K. L. Schmid, M. A. Ford, and A. R. Kolk. (2006). Internal egg temperature in response to preincubation warming in broiler breeder and turkey eggs. J. Appl. Poult. Res. 15:1-8.
Roque, L. and M.C. Soares, (1994). Effects of eggshell quality and broiler breeder age on hatchability. Poult. Sci., 73: 1838-1845.

Ruiz, J. and Lunam C.A. (2002). Effect of preincubation storage conditions on hatchability, chick weight at hatch and hatching time in broiler breeders. British Poultry Science; 43:374383.

SAS Institute. (2006). SAS Users Guide: Statistics. Version 9.0 SAS Institute, Cary, NC.

Silva, F. H. A., D. E. Faria, K. A. A. Torees, D. E. Faria Filho, A. A. D. Coelho, and V. J. M. Savino. (2008). Influence of egg pre- storage heating period and storage length on incubation. Braz. J. Poult. Sci. 10:1-11.

Tarongoy, Jr., F. Eduave and E.K. Gemota, (1990). Age as a factor of hatchability. SWUCA-J. Agric. Res. (Philippines), 5: 22-26

Tona, K., Bamelis, F., De Ketelaere, B., Bruggeman, V., Moraes, V.M.B., Buyse, J., Onagbesan, O., Decuypere, E. (2003). Effects of egg storage time on spread of hatch, chick quality, and chick juvenile growth. Poult. Sci.,82:736-741.

Uddin M.S., Paul D.C., Huque Q.M.E. (1994). Effect of egg weight and pre-incubation holding periods on hatchability of Japanese quail eggs in different seasons. Asian-Australas. J. Anim. Sci., 7, 499 503.

Van de Ven, L., (2004). Storage of hatching eggs in the production process. International Hatchery Practices, 18, 27-31.

Weis, J., (1991). Analysis of fertility, hatchability and egg quality indices in reproduction breeding of guinea fowls. Acta Zootechnica Universitatis Agriculturae (CSFR). Number 47 pp: 5-15.

Yassin H., Velthuis A., Boerjan M., van Riel J., and Huirne R., (2008). Field study on broiler eggs hatchability. Poult. Sci., 87:2408-2417.

\footnotetext{
تأثير التسخين لفترات قصيرة للبيض المخزن فترات طويله علي الفقس والتفوق الجنيني وجودة الكتاكيت

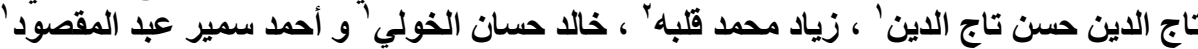

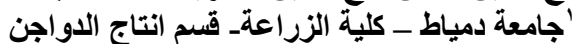

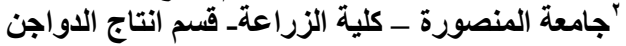

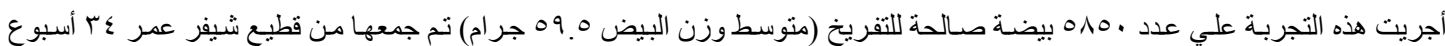

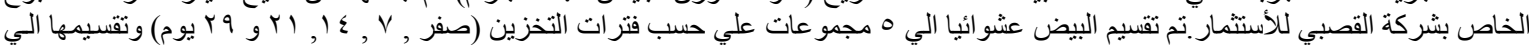

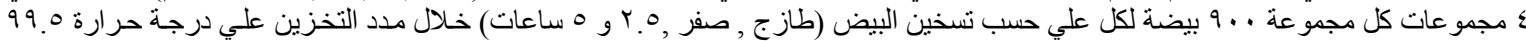

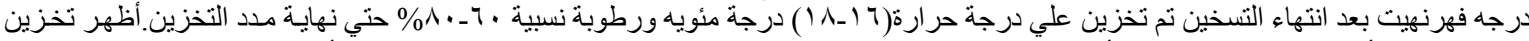

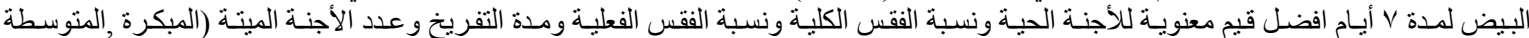

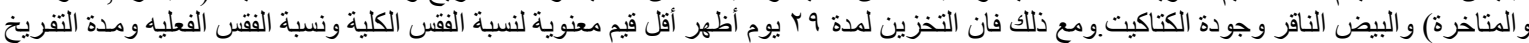

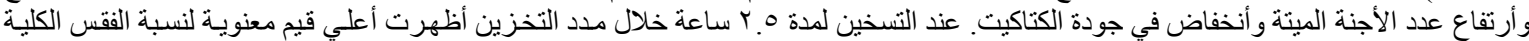

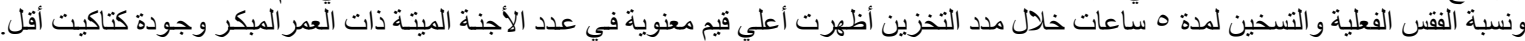

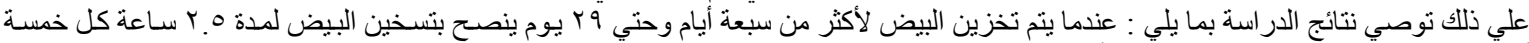
أيام من فترة التخزين وذللك للحصول علي ألحة أحسن النتائج.
} 